\title{
PREDICTORS OF NO-REFLOW PHENOMENON: DIABETES MELLITUS TYPE II AND OBESITY AND THEIR ASSOCIATED MORTALITY IN STEMI PATIENTS AFTER PRIMARY PCI
}

Larisa Renata Pantea-Roșan ${ }^{1,2}$, Otilia Anca Țica ${ }^{1,2}$, Mădălina Moisi $i^{1,2}, V$ Vlad Alin Pantea ${ }^{1}$,

Ovidiu Țica ${ }^{1,2}$, Cosmin Vesa ${ }^{1,2}$, Katalin Babeș ${ }^{1,2}$, Mihaela Popoviciu $^{1,2}$,

Mircea loachim Popescu, ${ }^{1,2}$

${ }^{1}$ University of Oradea, Faculty of Medicine and Pharmacy

${ }^{2}$ Clinical County Emergency Hospital of Oradea

Corresponding author: Iarisa.rosan@yahoo.com

Rezumat

Decelarea fenomenului no-reflow in urma PCI primar la pacientii cu STEMI reprezintă un factor de risc negativ pe termen scurt si lung in ceea ce priveste supravietuirea comparativ cu pacientii care nu asociaza fenomenul. Acest fapt este cu atât mai important in ceea ce priveste mortalitatea pacientilor cu cât s-a dovedit ca exista o corelatie intre fenomenul no-reflow si diabetul zaharat de tip II si obezitate.

Cuvinte cheie: fenomenul no-reflow, diabet zaharat, obezitate

\section{Abstract}

The prognosis of STEMI patients experiencing the no-reflow phenomenon is unfavorable both in the short- and long-term compared to patients who do not develop this pathology, and it is even worse as other cardiovascular risk factors There is a correlation between the no-reflow phenomenon and diabetes mellitus type II and obesity and this conditions represent stong predictors of mortality.

Keywords: no-reflow phenomenon, diabetes mellitus, obesity 


\section{INTERNAL}

\section{Original papers}

\section{Introduction}

The no-reflow phenomenon is met by percutaneous coronary intervention in patients who have had a ST segment elevation myocardial infarction, the failure of blood flow to the coronary microcirculation despite the effective disintegration of the artery involved ${ }^{(1)}$.

Diabetes mellitus is a heterogeneous group of disorders with significant lipid and proteinrelated consequences, with hyperglycaemia. At macrovascular level there is an alteration of medium and small blood vessels resulting from the association of several cardiovascular risk factors. Myocardial ischemic suffering is caused by the occurrence of macroangiopathy involving atherosclerotic pathology, microangiopathy where small diameter vessels and dismetabolic myocardiopathy ${ }^{(2)}$.

Obesity contributes directly to the alteration of glucose and lipid metabolism, favoring the development of atheromatous plaques, which is mainly explained by the production of negative proinflammatory elements ${ }^{(3)}$.

The prognosis of STEMI patients experiencing the no-reflow phenomenon is unfavorable both in the short- and long-term compared to patients who do not develop this pathology, and it is even worse as other cardiovascular risk factors ${ }^{(4)}$.

\section{Objectives}

Highlighting the impact of type II diabetes mellitus and obesity on coronary microcirculation compared with people who do not have this pathology, meaning an important element in determining acute myocardial infarction with subsequent post-angiographic development of the no-reflow phenomenon.

\section{Material and method}

A study was conducted which included 656 patients with ST segment elevation acute myocardial infarction, admitted to the Cardiology Clinic of Oradea County Emergency Clinical Hospital between 01.01.2016 and 31.03.2018, who were revacculated myocardial with primary $\mathrm{PCl}$. The no-reflow phenomenon after angiography was observed in 96 patients, of whom 42 had type II diabetes. Patients were evaluated both clinically and paraclinically by weighing, electrocardiography before and after $\mathrm{PCl}$, angiographic, echocardiographic and biological. Basal blood glucose values were monitored for both known diabetic patients and those with over-normal values, and glycosylated hemoglobin was determined in patients who had repeatedly elevated glycemic levels or in known diabetic patients. Thus, the STEMI and diabetes diagnosis was established following the anamnesis and the objective examination as 


\begin{tabular}{|c|c|c|c|c|c|}
\hline \multirow{2}{*}{ Diabetes mellitus } & \multicolumn{2}{|c|}{ Normal flow } & \multicolumn{2}{|c|}{ No-reflow } & \multirow{2}{*}{$\begin{array}{l}\text { Incidenţa } \\
\text { No-reflow }\end{array}$} \\
\cline { 2 - 5 } & Nr. & $\%$ & Nr. & $\%$ & 11,51 \\
\hline Whitout Diabetes & 415 & 74,11 & 54 & 56,25 & 22,46 \\
\hline With Diabetes & 145 & 25,89 & 42 & 43,75 & 17,86 \\
\hline $\begin{array}{c}\text { Diabetes mellitus } \\
\text { insulin-depended }\end{array}$ & 69 & 12,32 & 15 & 15,63 & 26,21 \\
\hline $\begin{array}{c}\text { Diabetes mellitus } \\
\text { non insulin- } \\
\text { dependent }\end{array}$ & 76 & 13,57 & 27 & 28,13 & \\
\hline
\end{tabular}

Table 1. Incidence of no-reflow phenotype in type II diabetes mellitus

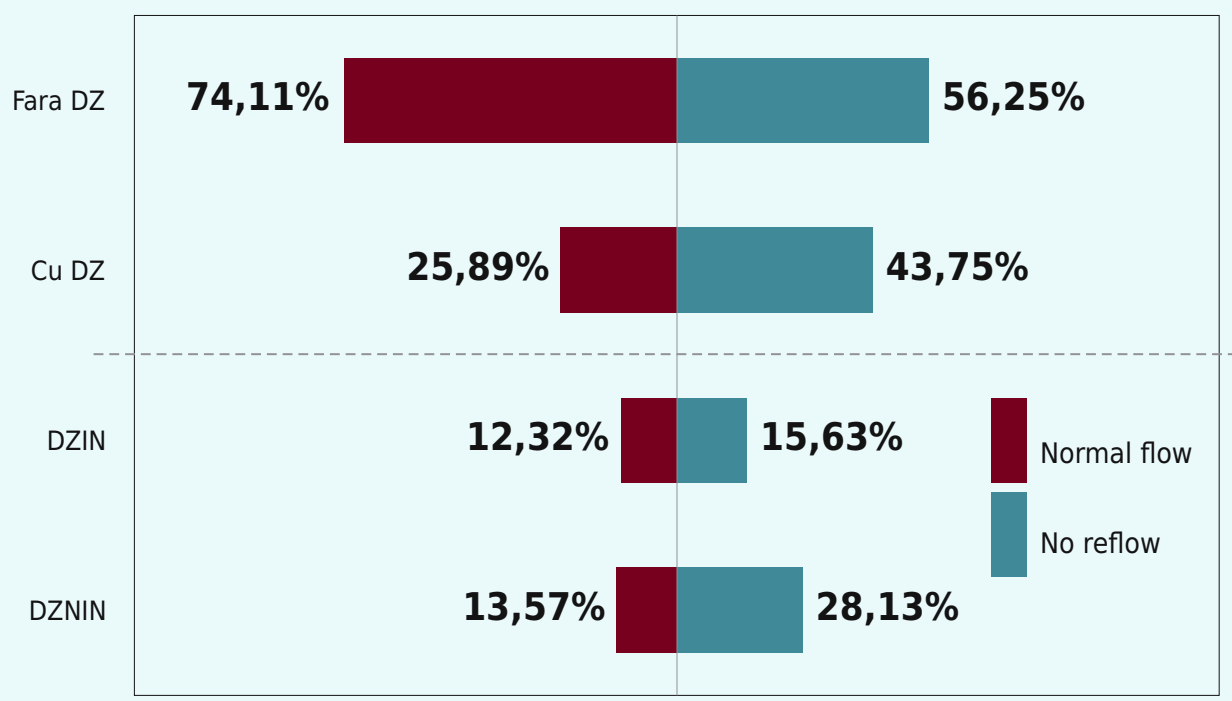

Figure 1. Distribution based on diabetes

\begin{tabular}{|c|c|c|c|c|c|}
\hline \multirow{2}{*}{ Obesity } & \multicolumn{2}{|c|}{ Normal flow } & \multicolumn{2}{c|}{ No-reflow } & Incidența \\
\cline { 2 - 5 } & Nr. & $\%$ & Nr. & $\%$ & \\
\hline Normal weight & 346 & 61,79 & 50 & 52,08 & 12,63 \\
\hline Obese & 214 & 38,21 & 46 & 47,92 & 17,69 \\
\hline Obese gr.1 & 91 & 16,25 & 16 & 16,67 & 14,95 \\
\hline Obese gr.2 & 94 & 16,79 & 22 & 22,92 & 18,97 \\
\hline Obese gr.3 & 29 & 5,18 & 8 & 8,33 & 21,62 \\
\hline
\end{tabular}

Tabel 2. The incidence of no-reflow phenomenon depending on obesity 


\section{INTERNAL}

\section{Original papers}

well as after the paraclinical investigations. According to current guidelines, diabetes mellitus is considered if type II diabetes is considered to be> $126 \mathrm{mg} \mathrm{/} \mathrm{dl} \mathrm{and}$ glycosylated hemoglobin $>6.5 \%{ }^{(5)}$, and obesity is determined from $\mathrm{BMI} \geq 30 \mathrm{~kg} / \mathrm{m}^{2^{(6)}}$.

\section{Statistical analysis}

The statistical analysis was performed using SPSS 19. We calculated frequency ranges, odds ratio (OR) and 95\% confidence interval. The statistical significance was attributed to $p<0.05$ value.

\section{Results}

Diabetes mellitus was recorded in 1: 4 of the patients in the Normal flow group and in almost 1: 2 of the patients in the No-reflow group ( $p=0.001$ ). Insulin-dependent diabetes had a lower insignificant frequency in the Normal flow vs. the No-reflow group (12.32\% vs. $15.63 \%, p=0.370)$, whereas the prevalence of non-insulin-dependent diabetes was significantly lower in patients in the Normal flow group $(13.57 \%$ vs. $28.13 \%$, p $<0.001$ ). The incidence of no-reflow was $11.51 \%$ in non-diabetic patients, significantly lower than in diabetics $(22.46 \%, p=0.001)$, especially in non-insulin dependent diabetics $(26.21 \%, p<0.001)$. The risk of no-reflow phenomenon is nearly 2 times higher in diabetics than non-diabetics (OR $=1.951,95 \%$
$\mathrm{Cl}$ : 1.353-2.813, $\mathrm{p}<0.001$ ), the risk being higher for non-insulin-dependent diabetics = 2.277, 95\% Cl: 1.511-3.430, p \& It; 0.001). For insulin-dependent diabetics, the no-reflow risk is 1.6-fold higher than for nondiabetics (OR = 1.551, 95\% Cl: 0.916-2.616, $\mathrm{p}=0.010)$. Obesity was present in $38.21 \%$ of normal flow patients and $47.92 \%$ of patients in the Noreflow group ( $p=0.073$ ). The prevalence of 2 and 3 obesity was significantly higher in No Refow patients than in Normal flow group (31.25\% vs $21.97 \%, p=0.047$ ). The risk of the no-reflow phenomenon is 1.4 times higher in obese patients than in normoponerals (OR = $1.401,95 \% \mathrm{Cl}: 0.969-2.059, \mathrm{p}=0.073)$, the risk being higher for ob $23(\mathrm{OR}=1.502,95 \%$ $\mathrm{Cl}: 0.704-1.994, \mathrm{p}=0.081, \mathrm{OR}=1.551,95 \%$ $\mathrm{Cl}: 0.916-2.616, \mathrm{p}=0.010)$. Mortality in patients with diabetes was significantly higher than in non-diabetic patients $(21.43 \%$ vs $9.26 \%, p=0.026)$. The risk of postPCl death in diabetic patients 2.7-fold greater than nondiabetics (OR $=2.6727,96 \% \mathrm{Cl}$ : 0.822 8.689). Regarding normoponderal, ob 2 and 3 obesity represent a postPCl mortality risk factor $(\mathrm{OR}=2,000,95 \% \mathrm{Cl}: 0,482-8,307, \mathrm{p}=$ 0,033 in obesity gr. $2, \mathrm{OR}=5,400,95 \% \mathrm{Cl}$ : $0.983-29.668, p=0.025$ on obesity gr. 3 ).

\section{Discussions}

This study demonstrates a link between Type II diabetes associated with varying degrees of 


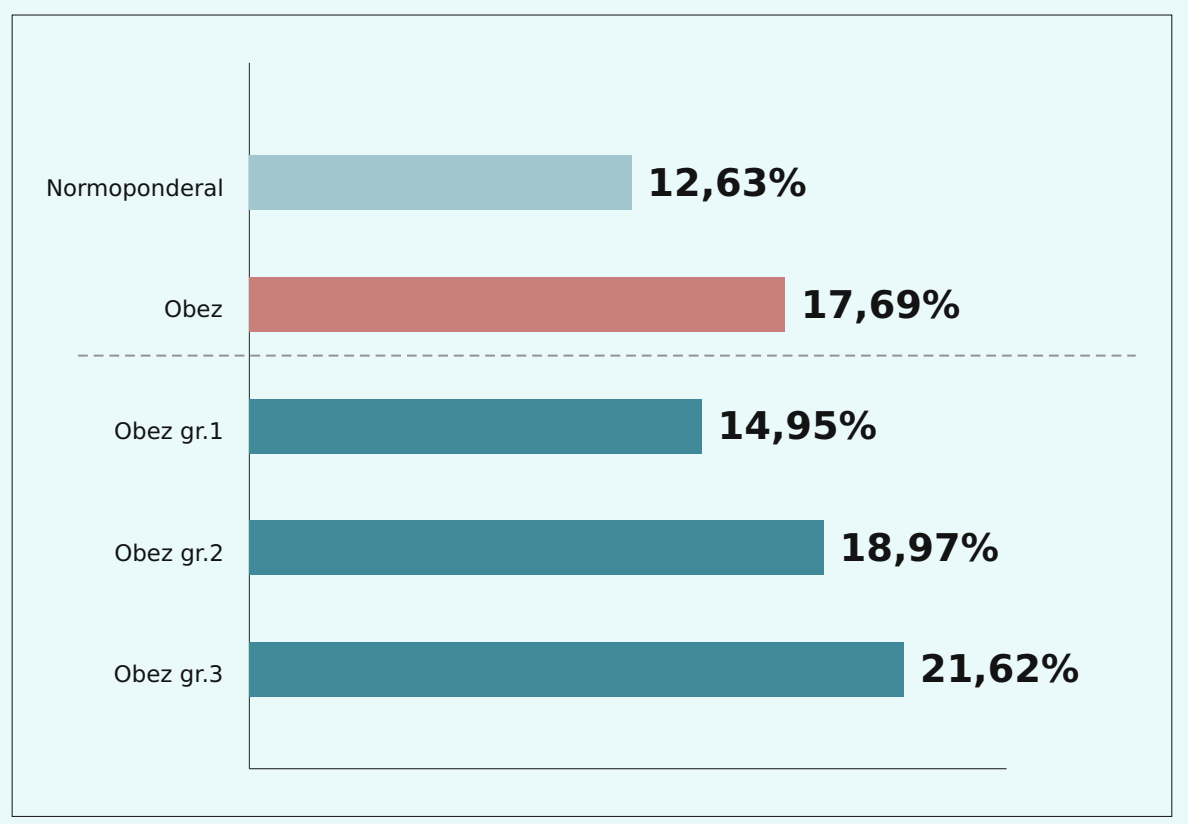

Figure 2. The incidence of no-reflow phenomenon depending on obesity

\begin{tabular}{|c|c|c|c|}
\hline Diabetes mellitus & & & \\
\hline No & 54 & 5 & 9,26 \\
\hline Yes & 42 & 9 & 21,43 \\
\hline Diabetes mellitus type II ID & 15 & 3 & 20,00 \\
\hline $\begin{array}{c}\text { Diabetes mellitus type II } \\
\text { NID }\end{array}$ & 27 & 6 & 22,22 \\
\hline Obesity & 50 & 5 & 10,00 \\
\hline No & 46 & 9 & 19,57 \\
\hline Yes & 16 & 2 & 12,50 \\
\hline Obese gr.1 & 22 & 4 & 18,18 \\
\hline Obese gr.2 & 8 & 3 & 37,50 \\
\hline Obese gr.3 & & & \\
\hline
\end{tabular}

Tabel 3. Mortality depending on the association of type II diabetes and obesity 


\section{INTERNAL}

\section{Original papers}

affection and no-reflow phenomenon. The study also notes the link between the rise of the no-reflow phenomenon correlated with the presence of diabetes and obesity with increased mortality risk in these patients. Furthermore, the study may be associated with other studies that have emphasized that the presence of a history of myocardial infarction correlated with the presence of these cardiovascular risk factors may be a predictor of the occurrence of the no-reflow phenomenon $^{(7)}$.

\section{Conclusions}

Unlike other studies in the field, it emphasizes the importance of systematically performing basal glycaemia followed by glycosylated hemoglobin, as well as BMI in the risk of detecting the no-reflow phenomenon and mortality compared to patients who do not associate these pathologies .

\section{Bibliography}

1. Camici PG, Crea F. Coronary microvascular dysfunction. The New England journal of medicine, 2007, 356(8):40-830

2. Gherasim și colab. Medicină internă, Volumul II Bolile cardiovasculare metabolice, Ed. Medicală, București 1998; 1167- 1297

3. Ionescu DD. Factorii de risc și ateroscleroza. Mereuță A. Cateterismul cardiac și angiografia cardiacă și coronariană. Bucșa $A$, Deleanu D. Intervențiile coronariene percutane. Ginghină $C$, Călin A. Infarcutul miocardic acut. În: Apetrei E, Cuculici GhP, Gheorghiu AW. Cardiologie clinică, București, Edit. Medicală Callisto 2015; 69-79, 227-241, 476-516, 517-541.

4. Tatu-Chițoiu G, Tatu-Chițoiu A, Lăcău S. Electrocardiograma în reperfuzia miocardică, Edit. Medicală Antaeus, București, 2014, pag. 333

5. Authors/Task Force Members1, Rydén L, Grant PJ, Anker SD, Berne C, Cosentino F, Danchin N, Deaton C, Escaned J, Hammes HP, Huikuri H, Marre M, Marx N, Mellbin L, Ostergren J, Patrono C, Seferovic P, Uva MS, Taskinen MR, Tendera M, Tuomilehto J, Valensi $P$, Zamorano JL; ESC Committee for Practice Guidelines (CPG), Zamorano JL, Achenbach S, Baumgartner H, Bax J, Bueno $H$, Dean V, Deaton C, Erol C, Fagard R, Ferrari R, Hasdai $D$, Hoes AW, Kirchhof $P$, Knuuti J, Kolh $P$, Lancellotti $P$, Linhart A, Tamargo JL, Torbicki A, Wijns W, Windecker S; Document Reviewers, De Backer G, Sirnes PA, Ezquerra EA, Avogaro A, Badimon L, Baranova E, Baumgartner $H$, Betteridge J, Ceriello A, Fagard R, Funck-Brentano C, Gulba DC, Hasdai D, Hoes AW, KjekshusJK, Knuuti J, Kolh P, Lev E, Mueller C, Neyses L, Nilsson PM, Perk J, Ponikowski P, Reiner Z, Sattar N, Schächinger V, Scheen A, Schirmer $H$, Strömberg A, Sudzhaeva S, Tamargo JL, Viigimaa $M, S C$ Guidelines on diabetes, pre-diabetes, and cardiovascular diseases developed in collaboration with the EASD, The Task Force on diabetes, pre-diabetes, and cardiovascular diseases of the European Society of Cardiology (ESC) and developed in collaboration with the European Association for the Study of Diabetes (EASD). European Heart Journal 2013, 39(34): 87-3035

6. Yumuk V, Tsigos C, Fried M, Schindler K, Busetto $L$, Micic D, Toplak H. European Guidelines for Obesity Management in Adults. European Journal of Obesity, 2015, 6(8):402-424

7. Smyth A., O'Donnell M., Lamelas P., Teo K., Rangarajan S., Yusuf S.. Physical activity and anger or emotional upset as triggers of acute myocardial infarction: The INTERHEART Study. Circulation 2016; 15(134):10591067 